Published in final edited form as:

J Am Chem Soc. 2004 May 19; 126(19): 6115-6123. doi:10.1021/ja031691c.

\title{
Bioactivation and Cell Targeting of Semiconductor CdSe/ZnS Nanocrystals with Phytochelatin-Related Peptides
}

\author{
Fabien Pinaud $^{\dagger}$, David King ${ }^{\S}$, Hsiao-Ping Moorell, and Shimon Weiss ${ }^{\dagger, \ddagger}$ \\ Department of Chemistry \& Biochemistry, Department of Physiology, University of California Los \\ Angeles, Los Angeles, California 90095, Howard Hughes Medical Institute, and Department of \\ Molecular \& Cell Biology, University of California Berkeley, Berkeley, California 94720
}

\begin{abstract}
Synthetic phytochelatin-related peptides are used as an organic coat on the surface of colloidal $\mathrm{CdSe} / \mathrm{ZnS}$ semiconductor nanocrystals synthesized from hydrophobic coordinating trioctyl phosphine oxide (TOPO) solvents. The peptides are designed to bind to the nanocrystals via a Cterminal adhesive domain. This adhesive domain, composed of multiple repeats of cysteines pairs flanked by hydrophobic 3-cyclohexylalanines, is followed by a flexible hydrophilic linker domain to which various bio-affinity tags can be attached. This surface coating chemistry results in small, buffer soluble, monodisperse peptide-coated nanoparticles with high colloidal stability and ensemble photophysical properties similar to those of TOPO-coated nanocrystals. Various peptide coatings are used to modulate the nanocrystal surface properties and to bioactivate the nanoparticles. CdSe/ZnS nanocrystals coated with biotinylated peptides efficiently bind to streptavidin and are specifically targeted to GPI-anchored avidin-CD14 chimeric proteins expressed on the membranes of live HeLa cells. This peptide coating surface chemistry provides a novel approach for the production of biocompatible photoluminescent nanocrystal probes.
\end{abstract}

\section{Introduction}

Cadmium chalcogenide semiconductor nanocrystals (NCs) are very promising luminescent probes. ${ }^{1,2}$ These crystallite clusters of semiconductors, also known as quantum dots, have a size of 1 to $8 \mathrm{~nm}$ and exhibit unique optical properties that arise from quantum confinement effects characteristic of these small dimensions. ${ }^{3,4}$ Their high photostability, controllable and narrow emission bands (25-35 nm full width half-maximum), in addition to their broad absorption spectra and quantum yield as high as $85 \%^{5}$ offer significant advantages over conventional fluorescent dyes and may revolutionize fluorescence microscopy techniques. ${ }^{6}$ The remarkable photophysical properties of $\mathrm{CdSe}$ NCs throughout the visible range and

\footnotetext{
Correspondence to: Fabien Pinaud; Shimon Weiss.

†Department of Chemistry \& Biochemistry.

*Department of Physiology, University of California Los Angeles.

\$Howard Hughes Medical Institute.

|lDepartment of Molecular \& Cell Biology, University of California Berkeley.

Supporting Information Available: Purification of peptide-coated NCs, electrophoresis of three sizes CdSe/ZnS with positively charged peptide 10, aqueous solubilization of CdSe cores with peptides, FTIR characterization, NCs Stoke's radii calculation, gel shift assays with avidin and NeutrAvidin, and live HeLa cells internal labeling localization are available as Supporting Information. This material is available free of charge via the Internet at http://pubs.acs.org.
} 
their relatively easy synthesis have, therefore, generated tremendous interest for high sensitivity fluorescence microscopy imaging of biological samples. ${ }^{6,7}$ Among the various routes for the production of $\mathrm{CdSe} \mathrm{NCs},{ }^{8}$ synthesis in hot hydrophobic coordinating solvents such as trioctyl phosphine oxide (TOPO) yield the best crystalline quality and monodisperse nanoparticles and allow very good control over their size dispersion. ${ }^{9-11}$ The luminescence properties and the photostability of these NCs are noticeably improved when a shell of higher band gap materials, such as $\mathrm{ZnS}$, is epitaxially grown around the CdSe cores. ${ }^{12,13} \mathrm{As}$ in the core synthesis, hydrophobic coordinating solvents permit the controlled growth of fairly uniform ZnS shells a few nanometers thick. Core/shell CdSe/ZnS NCs synthesized with TOPO surfactants are, however, highly hydrophobic and their use as luminescent probes for biological imaging requires a reliable surface chemistry in order to solubilize them in biological buffers. Ideally, this surface chemistry does not significantly affect the size, maintains the colloidal stability and the photo-physical properties of the nanoparticles and enables covalent attachment of biological affinity tags.

In recent years, various original surface chemistries enabling solvation of TOPO-coated semiconductor NCs in aqueous buffers have emerged. Organic dendrons, ${ }^{14}$ amphiphilic polymers, ${ }^{15}$ mercaptoalkanoic acid ligands, ${ }^{16-19}$ phospholipid micelles, ${ }^{20}$ cysteines, ${ }^{21}$ or silanization ${ }^{22,23}$ have all effectively solubilized CdSe or CdSe/ZnS luminescent probes in aqueous buffers and permitted their successful use for immuno-assays, ${ }^{19,21,24,25}$ fluorescence in situ hybridization, ${ }^{6,18}$ cell imaging $15,16,22,26-32$ and in vivo imaging. ${ }^{20,33}$ However, some of these surface chemistries require advanced synthetic capabilities, ${ }^{14}$ are time-consuming and difficult to reproduce, ${ }^{23}$ are not always applicable to all sizes of nanoparticles, ${ }^{20}$ or result in NCs with final diameters greater than $20 \mathrm{~nm} \cdot{ }^{34}$ Furthermore, hydrophilic monothiol ligands, which are the most often used, do not efficiently stabilize NCs. ${ }^{7}$ Desorption of the thiol ligands from the surface often result in aggregation of the nanoparticles. Improvements in stability have been achieved using dithiol ligands ${ }^{17}$ or adsorption of proteins, ${ }^{35}$ yet for mercaptoalkanoic acid surface ligands the NCs colloidal stability is $\mathrm{pH}$ sensitive and covalent bioconjugation has proven difficult. ${ }^{17}$

Despite the progress made in the past few years, the controlled interfacing of hydrophilic organic molecules with the inorganic surface of NCs remains an important challenge. Interestingly, when it comes to organic-inorganic interactions, very specialized and efficient processes have naturally evolved. A particularly remarkable example is the biosynthesis by some plants as well as some yeast and bacteria strains of cysteine-rich peptides called phytochelatins. Phytochelatins are synthesized by these organisms to detoxify their environment from transition metal ions such as $\mathrm{Cd}^{2+}$ (for a review ${ }^{36}$ ). In vivo, these peptides of structure $(\gamma-\mathrm{EC})_{n} \mathrm{G}$ (n, the number of dipeptide repeats, is typically $\left.2-4\right)$ complex metal ions into semiconductor NCs such as CdS. ${ }^{37,38}$ These intracellular peptide-coated NCs appear to be very stable and have photophysical properties similar to those of NCs synthesized chemically, but tend to degrade upon photoexcitation. ${ }^{39}$ From these initial observations, phytochelatin-related peptides with $\gamma$ and $a$-linkages have been used as templates for in vitro nucleation and growth of NCs such as ZnS or CdS. ${ }^{39,40}$ More recently, combinatorial approaches and phage display technology have been employed to optimize the interfacing of peptides with semiconductor nanoparticles. ${ }^{41-43}$ However, the use of NCs grown from peptide templates as probes for fluorescence microscopy has been rather 
limited. The probable cause is their lower crystalline quality as compared to similar NCs synthesized in hot coordinating solvents and the absence of higher band gap shell material on top of the semiconductor cores, which may result in rapid photodegradation.

On the basis of these naturally formed organic-inorganic hybrid materials, we designed synthetic a-peptides resembling the phytochelatins, which would efficiently bind on the surface of hydrophobic CdSe/ZnS NCs and provide buffer soluble, biocompatible, and photostable NCs probes suitable for live cell fluorescence imaging. In this report, we describe the aqueous buffer solubilization and the bioactivation of TOPO-coated $\mathrm{CdSe} / \mathrm{ZnS}$ nanoparticles with such peptides. This approach yields monodisperse and colloidally stable peptide-coated NCs with photophysical properties similar to those of their hydrophobic peers. Their relatively small size and high colloidal stability permit characterization via conventional biochemical techniques. Moreover, the NCs surface properties can be controlled and tuned using various peptide coatings or by reacting combinations of different peptides on the nanoparticles surface (Table 1). Finally, we describe the bioactivation of $\mathrm{CdSe} / \mathrm{ZnS}$ NCs with peptides bearing a biotin moiety and the specific targeting of these NCs to live HeLa cells expressing membrane-anchored avidin-CD14 chimeric proteins (avCD14).

\section{Experimental Section}

\section{Chemicals}

All chemicals were obtained from Sigma-Aldrich (St. Louis, MO) or Fisher Scientific (Tustin, CA).

\section{Synthesis of Peptides}

The peptides were purchased from Synpep (Dublin, CA) or synthesized by standard F-moc solid-phase synthesis. The purity was at least $80 \%$ for the commercial peptides and $95 \%$ for others. The identity and purity of the peptides were confirmed by ESI-ion trap mass spectrometry, and reversed-phase HPLC.

\section{Synthesis of CdSe/ZnS Core-Shell Nanocrystals and Solubilization with Peptides}

TOPO-coated CdSe/ZnS NCs were synthesized by rapid injection of dimethyl-cadmium and TOP-selenide precursors in hot TOPO using methods previously described. ${ }^{9}, 12,13,44$ Three sizes of CdSe cores: $2.4,3.2$, and $4.5 \mathrm{~nm}$ in diameter ${ }^{45}$ were over-coated with $4-5$ monolayers of $\mathrm{ZnS}$ and preserved in butanol/TOPO. The three $\mathrm{CdSe} / \mathrm{ZnS}$ batches used in this report consisted of green $(530 \mathrm{~nm})$, yellow $(565 \mathrm{~nm})$ and red $(617 \mathrm{~nm})$ emitting NCs.

For the reaction with peptides, TOPO-coated $\mathrm{CdSe} / \mathrm{ZnS}$ NCs were precipitated with methanol and redissolved in pyridine to a concentration of $1 \mu \mathrm{M} .{ }^{45}$ An excess of peptides, typically $4.0 \mathrm{mg}$ in $50 \mu \mathrm{L}$ DMSO, was then mixed with $450 \mu \mathrm{L}$ of the NCs solution. The surfactant exchange and the binding of peptides on the NCs were triggered by increasing the $\mathrm{pH}$ of the mixture above 10.0 with the addition of $12 \mu \mathrm{L}$ of tetramethylammonium hydroxide (TMAOH) 25\% (w/v) in methanol. The mixture was then quickly vortexed and centrifuged. The NCs precipitate obtained was redissolved in DMSO and eluted through a 
G-25 Sephadex desalting column (Amersham, Piscataway, NJ) equilibrated with water. The peptide-coated nanoparticles were then dialyzed against a PBS buffer $(50 \mathrm{mM} \mathrm{NaCl}, 10 \mathrm{mM}$ $\mathrm{Na}_{2} \mathrm{HPO}_{4}, \mathrm{pH}$ 7.2) to remove the excess of unbound peptides. Depending on the subsequent applications, the peptide-coated NCs were kept at $4{ }^{\circ} \mathrm{C}$ in the dialysis buffer, water, or buffers supplemented with $0.1 \%$ bovine serum albumin (BSA) for improved stability.

\section{Chromatographic and Electrophoresis Techniques}

Size exclusion gel chromatography (SE-HPLC) was performed on an Agilent 1100 series liquid chromatography system with G4000SWxl columns (Tosoh, Montgomeryville, PA) using a PBS mobile phase $\left(100 \mathrm{mM} \mathrm{NaCl}, 3 \mathrm{mM} \mathrm{KCl}, 2 \mathrm{mM} \mathrm{KH}_{2} \mathrm{PO}_{4}, 7 \mathrm{mM} \mathrm{Na}_{2} \mathrm{HPO}_{4} \mathrm{pH}\right.$ 7.2) at a flow rate of $0.5 \mathrm{~mL} / \mathrm{min}$. Absorbance and fluorescence detections were performed online during the separation. The Stoke's radii of the NCs were determined by the method of Laurent and Killander ${ }^{46}$ with a set of proteins standard of known Stoke's radii: Bovine thyroglobulin (85.0 $)$, bovine gamma globulin $(55.0 \AA)$, chicken ovalbumin $(27.3 \AA)$, horse myoglobin (18.8 $\AA$ ) and vitamin B-12 (7.5 $)$ (Biorad, Hercules, CA). The size of the peptide-coated NCs was calculated from the standard calibration curve by linear fitting the Stoke's radii versus $\left(-\log K_{\mathrm{av}}\right)^{1 / 2}$ (Supporting Information, Figure S-4).

Gel electrophoresis was performed on $0.5 \%$ and $1 \%$ agarose gels in TBE buffer $(89 \mathrm{mM}$ TRIS, $89 \mathrm{mM}$ Borate and 2mM EDTA, $\mathrm{pH} 8.3$ ) for $1 \mathrm{~h}$ at $120 \mathrm{~V}$. The fluorescent bands were detected on a FX fluorescence gel scanner (Biorad, Hercules, CA) with a laser excitation at $488 \mathrm{~nm}$ and appropriate emission filters. For the streptavidin assays, $200 \mathrm{nM}$ of NCs coated with biotinylated peptide 8 (Table 1) or nonbiotinylated peptides $\mathbf{4}$ or $\mathbf{6}$ were incubated in PBS pH 7.2 with various concentrations of streptavidin (Pierce, Rockford, IL) for $60 \mathrm{~min}$ at $25^{\circ} \mathrm{C}$ (Figure 6). After incubation, the sample were run on a 1\% agarose gel in TBE for $1 \mathrm{~h}$ at $120 \mathrm{~V}$ and imaged on a fluorescence gel scanner.

\section{Photophysical Characterization}

For spectra acquisitions, TOPO-coated NCs were precipitated with methanol and redissolved in toluene. Peptide-coated NCs were kept in PBS buffer. UV-vis absorption spectra were acquired on a Perkin-Elmer lambda $25 \mathrm{UV}$-vis spectrometer. Fluorescence spectra were acquired on a QM-6SE PTI fluorescence spectrometer with excitation at $400 \mathrm{~nm}$. Quantum yields for TOPO coated NCs in toluene and peptide-coated NCs in water were evaluated against Rhodamine 6G (EM Science, Gibbstown, NJ) in methanol for identical optical density at $488 \mathrm{~nm}$.

\section{Transmission Electron Microscopy}

TEM measurements were performed on a high-resolution Philips CM200 microscope. After methanol precipitation, red emitting TOPO-coated NCs in toluene were deposited on ultrathin carbon coated copper grids 400 mesh (Ted Pella, Redding, CA). Peptide-coated NCs were deposited from water. The size distribution analyses were performed from digital images of various fields of view by measuring the longest axis of the NCs with the instrument processing software Digital Micrograph (Gatan, Pleasanton, CA). The NCs diameters were then reported as a histogram with a $0.5 \AA$ binning. The size and width distributions were evaluated by Gaussian fitting of the histograms. 


\section{Atomic Force Microscopy}

AFM measurements were conducted on a SPM microscope (Molecular Imaging, Thousand Oaks, CA). Images were acquired in "tapping mode" in air with a $\mathrm{SiO}_{2}$ cantilever. After methanol precipitation, TOPO-coated NCs, redissolved in butanol, were spin-coated on mica. For the peptide-coated samples, the NCs were diluted in acidified water ( $\mathrm{pH} 4)$ and also spin-coated on mica. Images were analyzed using a homemade Labview software. The NCs height values were then reported on a histogram with a $0.5 \AA$ binning. The size and width distributions were evaluated by Gaussian fitting of the histograms.

\section{Construction of Avidin-CD14 Chimera and Cell Targeting}

A glycosylphosphatidylinositol (GPI)-anchored avidin construct was made to introduce avidin to the cell membrane of HeLa cells. The full-length chicken avidin (Genbank accession no. X05343, amino acid 1 to 153 including signal sequence) was modified by PCR with the following primers to add a $5^{\prime}$-Hind III and a $3^{\prime}$-Bam HI site: sense, $5^{\prime} \operatorname{cgc}$ ggg aag ctt gec acc atg gtg cac gea acc tcc $3^{\prime}$; anti-sense, $5^{\prime}$ cgc ggg gga tcc ctc ctt ctg tgt geg cag $3^{\prime}$. The signal for GPI-anchor from human CD14 (Genbank accession no. M86511, amino acid 318 to 376 encompassing the stalk region and the transmembrane region) was PCR amplified with the following primers to add a $5^{\prime}$-Bam HI and a $3^{\prime}$-NOT I site: sense, $5^{\prime} \mathrm{cgc}$ ggg gga tcc ctg ccc gag gtg gat aac $3^{\prime}$; anti-sense, $5^{\prime}$ cgc ggg cgc cgg cga aat ccg ttt cgg ggc gcg $3^{\prime}$. Both fragments were then cloned into the mammalian expression vector, pcDNA3 (Invitrogen, Carlsbad, CA) via Hind III and NOT I sites. The resulting avidin-CD14 (avCD14) plasmid contains the full-length avidin fused in-frame to the GPI-anchor sequence of CD14. HeLa cells were transfected with the av-CD14 plasmid using Effectene reagent (Qiagen, Valencia, CA) and selected with $0.75 \mathrm{mg} / \mathrm{mL}$ G418 (Invitrogen, Carlsbad, CA). The transfected HeLa cells were grown in DMEM media supplemented with 5\% fetal calf serum (FCS) to $60 \%$ confluency on fibronectin coated coverslips. The cells were kept at $37^{\circ} \mathrm{C}$ through all steps until the imaging. For 3 to $4 \mathrm{~h}$ prior to the staining experiments, the cells were starved in DMEM media to free the av-CD14 proteins from biotin present in the FCS supplement and to avoid competition with the biotinylated probes. The cells were preincubated in a HBSS +1\% BSA buffer for 20 min and rinsed with HBSS $(10 \mathrm{mM}$ glucose, $20 \mathrm{mM}$ Hepes, $1.2 \mathrm{mM} \mathrm{Na}_{2} \mathrm{HPO}_{4}, 1.2 \mathrm{mM} \mathrm{MgSO}_{4}, 145 \mathrm{mM} \mathrm{NaCl}, 5 \mathrm{mM} \mathrm{KCl}, 2$ $\mathrm{mM} \mathrm{CaCl} 2$, pH 7.4). Biocytin Alexa 594 (200 nM) (Molecular Probes, Eugene, OR), biotinylated $(10 \mathrm{nM})$ or nonbiotiny-lated $(10 \mathrm{nM}) \mathrm{CdSe} / \mathrm{ZnS}$ NCs emitting at $617 \mathrm{~nm}$ were then incubated on the cells in HBSS $+1 \%$ BSA for $20 \mathrm{~min}$. The cells were rinsed with HBSS buffer and imaged in $37^{\circ} \mathrm{C}$ HBSS on an inverted Axiovert Zeiss microscope (Thornwood, NY) equipped with a $63 \times$ oil-immersion (1.4 NA) objective, a $100 \mathrm{~W}$ mercury lamp and a CoolSnap CF CCD camera (Roper Scientific, Tucson, AZ). Biocytin Alexa 594 was imaged with a 560 BP55 excitation filter, a 595 LP dichroic mirror and a 645 BP75 filter for emission (Chroma, Rockingham, VT). A 500 SP excitation filter, a 505 DRLP dichroic mirror and a 645 BP75 emission filter were used for the NCs. 


\section{Results}

\section{Peptide Coating of CdSe/ZnS Nanocrystals}

The reaction of a typical phytochelatin-related synthetic a-peptide on the surface of $\mathrm{CdSe} / \mathrm{ZnS}$ NCs is presented in Figure 1. The 20 amino acid long amphiphilic peptide has a hydrophobic adhesive domain allowing the binding on the ZnS surface of the NCs and a negatively charged and hydrophilic linker domain that can be modified to include binding sequences or functional groups for conjugation. Cysteinyl thiolates, present in the adhesive domain, have previously been shown to act as surface ligands on CdS and ZnS NCs. ${ }^{21,38,47}$ The replacement of these cysteine residues $(\mathrm{C})$ by alanine resulted in water insoluble particles (data not shown), and confirmed that the presence of cysteine allows the attachment of the peptides on the nanoparticle surface. Multiple repeats of cysteine in tandem were chosen to enhance the coverage and the stability of the peptides on the NCs surface.

Adhesive domains limited to one repeat only were not adequate to obtain stable NCs. Such length-dependent stability has been previously observed for CdS NCs coated with phytochelatin peptides of various lengths. ${ }^{39}$ The formation of aggregates during the reaction could be prevented by dissolving both the peptides and the TOPO-coated NCs in 9:1 (v:v) pyridine:DMSO cosolvent. The presence of hydrophobic 3-cyclohexylalanine (Cha) residues around the cysteines of the adhesive domain helped the solubilization of the peptides in this apolar cosolvent. The large cyclohexyl moieties were also chosen to limit the crossreactivity between the cysteines of the adhesive domain and to compete with the hydrophobic TOPO on the NCs surface. When the Cha residues were replaced by alanine, the obtained peptide-coated NCs were unstable in buffers (data not shown).

The binding of the peptides on the $\mathrm{ZnS}$ layer was triggered by forming cysteine thiolates anion with the addition of tetramethylammonium hydroxide (TMAOH) base. TMAOH has previously been shown also to effect the removal of TOPO from the surface of CdSe/ $\mathrm{ZnS}$ NCs. ${ }^{31}$ Upon binding of the peptides, the nanoparticles precipitate out of the cosolvent, and can be redissolved in DMSO and water. The excess of un-bound peptides was then removed by dialysis or centrifugal filtration and the purification was assessed by size exclusion liquid chromatography (SE-HPLC) and SDS-PAGE gel electrophoresis (Supporting Information, Figure S-1).

Peptide 1 (Table 1), composed of the adhesive domain only, could efficiently solubilize $\mathrm{CdSe} / \mathrm{ZnS}$ in DMSO and water but the NCs aggregated at $\mathrm{pH} 7.2$ in PBS buffers above 5 $\mathrm{mM}$. The addition of a polar second domain to the peptide sequences, such as that of peptide 2, improved the stability in PBS buffers with ionic strength up to $20 \mathrm{mM}$, though the NCs formed small aggregates above this molarity. When a polar but positively charged domain containing arginine residues $(\mathrm{R})$ (peptide $\mathbf{3}$ ) was used to enhance the stability of the particles in higher ionic strength buffers, the NCs readily aggregated upon water solubilization. These aggregations may have arisen from the interaction of the positively charged arginine residues with the negatively charged surface of the NCs. To overcome these charge interactions, a polar but negatively charged domain containing glutamic acid residues (E) (peptide 4) was tested, and successfully conferred both solubilization and colloidal stability to the 
nanoparticles in PBS buffers containing $100 \mathrm{mM}$ and higher salt. This domain was thus chosen as a hydrophilic linker addition for other peptides sequences.

As shown in Figure 2a, three sizes of CdSe/ZnS NCs coated with peptide 5 could be separated on a SE-HPLC column. This separation by size was also observed by gel electrophoresis where the NCs have different relative migration distances (Figure 2b). Similar separations of different NCs sizes were obtained after coatings with peptides 4, 6, 7, 8, and 10 (Supporting Information, Figure S-2). The small width of the bands observed in gels and the Gaussian shape of the nanoparticle elution peaks by SE-HPLC reflect the narrow size distribution of the peptide-coated nanocrystal samples and indicate that the coating is uniform and does not lead to aggregations. Individual peptides or mixtures of the peptides depicted in Table 1 successfully solubilized core-shell CdSe/ZnS as well as CdSe core NCs (Supporting Information, Figure S-3). The presence of peptides around the soluble NCs was confirmed by infrared spectroscopy with the detection of the peptide bond amide I and II vibrational bands at 1650 and $1535 \mathrm{~cm}^{-1}$, respectively ${ }^{48}$ (Supporting Information, Figure S-4).

\section{Colloidal and Photophysical Properties of Peptide-Coated CdSe/ZnS Nanocrystals}

To evaluate the effect of the peptide coating on the monodispersion and the size of the NCs, TEM, and AFM statistical analyses were performed before and after coating (Figure 3). The diameter of the crystalline core/shell material was measured by TEM while AFM was carried out to assess the total size of the NCs, including the surfactants. Statistical measurements by TEM indicated sizes of $73.8 \AA( \pm 27 \%)$ and $73.7 \AA( \pm 24 \%)$ in diameter for TOPO and peptide-coated red emitting CdSe/ZnS NCs respectively (Figure 3a,b). AFM measurements on the same samples, performed to estimate the size increase related to the TOPO and peptides surfactants, revealed sizes of $70.7 \AA( \pm 27 \%)$ for TOPO and $55.2 \AA$ $( \pm 38 \%)$ for peptide-coated NCs (Figure 3c,d). Although the AFM measurements showed no significant changes in the width of the NCs size distribution, the detected sizes are lower than those measured by TEM. As reported by Ebenstein et al., ${ }^{49}$ AFM sizing of nanoparticles in air is very sensitive to attractive forces between tip and sample and often results in reduction of the acquired height. The size of the peptide-coated NCs was thus estimated from their Stoke's radii (rotational volume) as measured by SE-HPLC (Supporting Information, Figure S-5). Sizes of $129.4 \AA( \pm 15 \%), 150.3 \AA( \pm 16 \%)$, and $164.8 \AA( \pm 14 \%)$ in diameter where determined for the green, yellow and red core-shell CdSe/ZnS NCs of Figure 2a, respectively. For the red nanoparticles this radial increase of $45.5 \AA$ from the size of the core/shell material determined by TEM accounts for the peptide coating and possible interparticle hydrodynamic interactions or particle column interactions during the separation. Indeed this distance is slightly longer than the maximum length of the hydrophilic linker domain that is estimated at $38 \AA$ assuming an ideal extended $\mathrm{Ca}-\mathrm{Ca}$ distance of $3.8 \AA$ between each amino acid. The colloidal stability of the peptide-coated nanoparticles over long periods of time was further confirmed by agarose gel and SE-HPLC analyses showing no signs of aggregation in samples stored over two months at $4{ }^{\circ} \mathrm{C}$. The NCs are stable between $\mathrm{pH} 4.0$ to 10.0 (Table 1). 
Having determined that the peptide coating does not significantly affect the colloidal properties of the NCs, we evaluated the effect on their photophysical properties. Figure 4 shows that the absorption and emission spectra of the NCs are unchanged after peptide coating. No shift in peak maximum or increase of the bands full width half-maximum was observed for any of the peptides described in Table 1. Despite having no effects on the spectral properties of the NCs, the peptide coating did lead to a significant decrease in quantum yield (QY) for CdSe cores NCs with ZnS shells. TOPO-coated NCs batches with QY of 11 to $15 \%$ in toluene usually had a QY of 1 to $2 \%$ in water depending on the peptide coating. However, for CdSe cores having graded $\mathrm{CdS} / \mathrm{ZnS}$ shell ${ }^{50}$ the peptide coating did not lead to a decrease in QY. Peptide-coated CdSe/CdS/ZnS had QY of $16 \%$ in water.

\section{Modulation of the Nanocrystal Surface Properties and Bioactivation with Peptides}

Figure 5 presents the solubilization of green $\mathrm{CdSe} / \mathrm{ZnS}$ NCs with three peptides $(\mathbf{4}, \mathbf{5}$ and $\mathbf{6})$ having the same adhesive domains but differing charges in their hydrophilic linker domains. On SE-HPLC, all three NCs samples elute with similar retention times and have similar Stoke's radii (Figure 5b). However, when the NCs are separated by electrophoresis on agarose gels, three different relative migration distances are observed (Figure 5c). The distance of migration appears to be influenced by the charge of the peptides on the NCs surface. Although it is unclear how the cysteines contribute to the overall charge of the nanoparticles, the NCs coated with the most negatively charged peptide 5 migrate further toward the positive electrode than peptides $\mathbf{4}$ or $\mathbf{6}$, in good agreement with the calculated theoretical charge of each sequence at the $\mathrm{pH}$ of separation (Figure 5a). Such separations by charge were reproducible for all sizes of NCs (result not shown). Notice that the sequences tested are negatively charged. NCs coated with peptide 10, which is positively charged at $\mathrm{pH}$ 8.3, also migrate toward the positive electrode (Supporting Information, Figure S-2). Evidently, the peptide coatings influence the overall charge of the NCs but the migration appears dominated by a negative charge probably originating from the core/shell material itself.

The nanoparticles were then bioactivated with peptides bearing an N-terminal biotin. $\mathrm{CdSe} / \mathrm{ZnS}$ NCs solubilized with peptide $\mathbf{8}$ were tested for activity in a gel shift assay with streptavidin. As shown in Figure 6a, a clear binding of the biotinylated NCs to streptavidin is observed. The tetrameric nature of streptavidin leads to the aggregation of multiple NCs together, as observed from the widening and shifting of the nanocrystal bands with increasing concentrations of streptavidin. At $50 \mu \mathrm{g} / \mathrm{mL}$ of streptavidin, the size of the aggregates hinders entry into the gel. At higher streptavidin concentrations, the nanoparticles re-enter the gel as a narrow band of significantly shorter migration distance relative to the biotinylated NCs. From the bandwidth and position, the re-entering NCs have a homogeneous size and appear larger than the biotinylated NCs. This concentration dependent gel re-entry may be explained by the saturation of the NCs surface biotins with streptavidin, which prevent further aggregation. The same NCs coated with non-biotinylated peptides $\mathbf{4}$ or $\mathbf{6}$ did not bind to streptavidin, thus confirming the absence of nonspecific interactions between the nanoparticles and the proteins (Figure $6 \mathrm{~b}$ ). 
For NCs coated with peptide mixtures such as 1:1 molar ratio of peptides 8 and $\mathbf{4}$, good correlations between the saturating streptavidin concentrations and the amounts of biotinylated peptides used during the coating were observed (result not shown). However, with avidin, which is highly positively charge at physiological $\mathrm{pH}(\mathrm{p} I 10.0)$, only nonspecific interactions with the negatively charged NCs were observed. Incubation of avidin with both biotinylated and nonbiotinylated NCs yielded aggregates not related to the binding of biotins to avidin (Supporting Information, Figure S-6). Such electrostatic mediated binding of positively charged proteins on negatively charged CdSe/ZnS NCs has previously been reported. ${ }^{51}$ However with NeutrAvidin, a deglycosylated form of avidin ${ }^{52}$ which is not charged at physiological $\mathrm{pH}(\mathrm{p} I 6.3)$, good binding specificity of the biotinylated NCs was observed (Supporting Information, Figure S-6). In live-cell targeting assays the electrostatic interactions of the NCs with avidin were also absent. Although the nanoparticles coated only with biotinylated peptide 8 reacted well with streptavidin in solution, the binding efficiency was severely lowered for streptavidin fixed on solid supports such as 96 well plates. Reducing the amount of biotin on the surface of the NCs using mixtures of peptides 8 and 4 at different ratios did not improve the binding efficiency on solid phases. This problem of interaction could be solved by coating the NCs with a 1:1 molar ratio of biotinylated peptide 8 and shorter hexa-ethyleneglycol-modified peptide $\mathbf{9}$. The length difference between the two peptides allows a better exposure of the biotin moieties and might lead to a better access to the streptavidin binding pockets (Figure 7).

\section{Targeting of Biotinylated CdSe/ZnS Nanocrystals in Live Cells}

To validate the biocompatibility of the peptide-coated NCs, we targeted biotinylated NCs to the cell membrane of HeLa cells expressing GPI-anchored avidin-CD14 (av-CD14) chimeric proteins (Figure 8). In initial control experiments, the cells were incubated with a biotinylated Alexa 594 fluorescent dye (Figure 8a-c). HeLa cells expressing the av-CD14 proteins are fluorescently labeled while cells not expressing the proteins are not stained. ${ }^{53}$ As expected, the cell membrane was homogeneously stained, but cytoplasmic compartments were also labeled. When the cells were incubated with biotinylated NCs coated with a 1:1 molar ratio of peptides $\mathbf{8}$ and $\mathbf{9}$, similar membrane and cytoplasmic staining patterns were observed (Figure 8d-f). Specific recognition of the av-CD14 proteins by the NCs on the cell membrane was confirmed by the absence of labeling for nonexpressing cells. Little nonspecific binding to the nonexpressing cells or to the fibronectin substrate was observed. As previously reported the presence of poly(ethylene glycol) (PEG) on the NCs surface reduces significantly non-specific adsorptions. ${ }^{20,28}$ The targeting specificity was further confirmed when incubation with nonbiotinylated NCs coated with a 1:1 molar ratio of peptides 4 and 9 revealed neither membrane nor cytoplasmic staining (Figure 8g-i). We did not observe nonspecific binding of the NCs to avidin as previously seen in gels. The BSA blocking step together with a possible change of the isolectric point of avidin after fusion to the CD14 GPI sequence and anchoring to the cell membrane may explain the absence of nonspecific interaction. The labeling of cytoplasmic compartments was further confirmed by confocal microscopy for both Alexa 594 and NCs probes. ${ }^{54}$ This internal staining occurs within 2-3 min of incubation with the probes and appears to be temperature dependent and perinuclear (Supporting Information, Figure S-7). No toxic effects of the NCs on the cells 
were observed. HeLa cells stained with NCs and further incubated for $24 \mathrm{~h}$ in DMEM media appeared healthy (result not shown).

\section{Discussion}

To use semiconductor NCs probes for live cell imaging, biocompatible and colloidally stable $\mathrm{CdSe} / \mathrm{ZnS}$ nanoparticles are required. We have developed a phytochelatin-related peptide surface coating chemistry for this purpose. The surface adhesive portion of these peptides, composed of three repeats of cysteine-tandems flanked by hydrophobic Cha residues, is able to bind to both core and core/shell CdSe/ZnS NCs. Similar to previous reports, ${ }^{39}$ we observed that multiple repeats of cysteines promote the solubility and enhance the colloidal stability of the NCs. Ideally, the length of the adhesive domain can be adapted to the size of the particles in order to better fit the surface curvature and to enhance the coverage efficiency. Lee et al. ${ }^{55}$ have demonstrated that various amino acid residues are able to bind to the surface of $\mathrm{ZnS}$ semiconductors. Although the presence of both cysteine and Cha residues in our peptide adhesive domain enabled the binding to CdSe/ZnS NCs synthesized from TOPO solvents, other amino acid residues might be employed. While the binding of cysteine thiols to $\mathrm{ZnS}$ surfaces by coordination to $\mathrm{Zn}^{2+}$ is well characterized, ${ }^{47}$ the role of the Cha residues remains to be clarified. Beyond favoring solubilization in a hydrophobic cosolvent, Cha residues may also actively participate in hydrophobic adsorption as well as ordering of the peptides on the nanoparticle surface.

The aggregation of the NCs when a positively charged hydrophilic domain is used in the peptide sequence, and the observation that the nanoparticles always migrate toward the positive electrode during gel electrophoresis regardless of the charge of the hydrophilic domain, suggest that the NCs are negatively charged after the coating procedure. We suspect that this charge is located at the surface of the NCs and originates from a reorganization of charges in the core/shell semiconductor material after binding of the adhesive domain.

As discussed in the Introduction, some surface chemistries result in NCs having insufficient stability in buffers or large sizes, making electrophoretic and chromatographic analyses of these nanoparticles difficult. The separation of different sizes of soluble peptide-coated NCs on agarose gels as well as on size-exclusion chromatographic columns illustrates the high stability of the peptide coating and its limited effect on the overall size and distribution of the particles. Such analyses permit rapid control of the quality and activity of the NCs and their conjugates prior to further applications. Although the observed Stoke's radii of the peptide-coated NCs are consistent with the presence of a single monolayer of peptides on the nanoparticle surface, we could not evaluate accurately the number of peptides per nanocrystal. We were unable to efficiently strip the peptides off the NCs surface and conventional protein assays reacted with the $\mathrm{CdSe} / \mathrm{ZnS}$ material giving high background signals that prevented the evaluation of meaningful values for the amount of peptide per NCs. Alternative methods are currently under study.

It has been reported that surface chemistries on $\mathrm{CdSe} / \mathrm{ZnS} \mathrm{NCs}$ do not lead to significant changes in the position of absorption and luminescence bands, but often affect the QY. ${ }^{23} \mathrm{We}$ did not observe changes in the spectral properties of $\mathrm{CdSe} / \mathrm{ZnS}$ NCs after peptide coating, 
but we did observe a significant decrease of the QY. This QY decrease appeared to vary by a few percent with the nature of the peptide. In fact, the QY of CdSe/ZnS NCs is strongly dependent on the environment ${ }^{6}$ and on surfactant molecules. ${ }^{5,56,57}$ This variation of QY as a function of peptide coatings opens possibilities to improve the luminescence properties of $\mathrm{CdSe} / \mathrm{ZnS} \mathrm{NCs}$ by varying the nature of the amino acids present in close proximity to the nanoparticle surface. An additional way to limit the decrease in QY is to modify the composition of the NCs shell. Although the QY of CdSe/ZnS NCs significantly dropped upon peptide coating, there was no decrease of $\mathrm{QY}$ for $\mathrm{CdSe}$ cores with graded $\mathrm{CdS} / \mathrm{ZnS}$ shells.

Despite the inherent negative charge on the surface of the core/shell material after the peptide coating, modulation of the NCs charge using various peptide sequences could be achieved. This confirmed that the surface properties of the particles can be tailored for specific applications. Changes in the amino acids' composition of the hydrophilic domain or chemical group modifications in the peptide sequences provide means of altering the $\mathrm{NCs}$ properties. For example, NCs coated with peptide 7 bearing a $\mathrm{N}$-terminal lysine residue could be successfully derivatized with succinimidyl esters of biotin and subsequently showed excellent binding to streptavidin (result not shown). Alternatively carbohydrates, specific binding sequences or signaling peptides such as the nuclear localization sequence PKKKRKV ${ }^{58}$ of peptide $\mathbf{1 0}$ may be integrated into the synthetic peptide sequence, providing bioactive NCs that can be directly used in biological assays without the requirements of conjugation chemistry.

The size of the NCs, the surface density of the ligands, and their distance from the particle surface are also important factors to consider in order to optimize the molecular interaction of the nanoparticles with biomolecules of interest. NCs coated with high surface density of biotinylated peptide $\mathbf{8}$ were unable to bind to streptavidin on solid phases, probably because both the biotin moieties and streptavidin had limited conformational freedom. Problems of interaction of $\mathrm{CdSe} / \mathrm{ZnS}$ NCs with their target have been previously reported. ${ }^{31}$ The surface landscape of the NCs is therefore critical for efficient recognition of biologically active molecules. The reaction of different length peptides at various ratios on the NCs helps optimize molecular interactions by influencing the NCs surface topography (Figure 7). The targeting of NCs probes to GPI-anchored av-CD14 proteins on the membrane of live HeLa cells reflects the importance of controlling the particles' surface landscape. Indeed, the biotin binding pockets of avidin are buried $9 \AA$ beneath the protein surface ${ }^{59}$ Efficient binding to av-CD14 proteins could only be achieved by coating the NCs with mixtures of short PEG-modified peptide 9 together with longer biotinylated peptide $\mathbf{8}$. This length difference, together with the reduced amount of biotinylated peptides on the NCs surface, confer sufficient conformational freedom for the biotins to access the buried avidin binding pockets on the cell membrane.

The ability to target peptide-coated NCs to live cells specifically and the observation that the NCs labeled av-CD14 proteins are rapidly internalized are good indications of the high stability and biocompatibility of these probes and confirm that they are well suited for live cell imaging. Peptide-coated NCs are able to enter crowded areas such as biological 
membranes, and can be employed for the detection and tracking of single proteins and vesicles in cells. ${ }^{54}$

\section{Conclusions}

TOPO-coated CdSe/ZnS nanocrystals are easily made buffer soluble and biocompatible using phytochelatin-related peptides as an organic coat. The peptide-coated nanoparticles are relatively small, have high colloidal stability and conserve their photophysical properties and a good quantum yield for $\mathrm{CdSe} / \mathrm{CdS} / \mathrm{ZnS}$ nanocrystals. The modulation of the nanocrystal surface properties is achievable by using various peptide coatings. Single step bioactivation of the nanoparticles with peptides bearing a ligand was demonstrated. This surface chemistry is very versatile and offers a new approach for the use of photoluminescent nanocrystal probes for cell imaging. It also complements existing methodologies. Peptides similar to those described here might be employed for the coating of other semiconductor and metallic nanocrystals, nanorods, and nanotubes. Moreover, with recent developments in peptide self-assembling systems, ${ }^{60}$ this approach might be useful for the controlled and programmed patterning of nanostructures based on peptide motif recognition.

\section{Supplementary Material}

Refer to Web version on PubMed Central for supplementary material.

\section{Acknowledgments}

The authors thank Paul Alivisatos for assistance in the synthesis of the nanocrystals, the FTIR measurements and for helpful comments, as well as Chris Nelson and the National Center for Electron Microscopy at the Lawrence Berkeley National Laboratory for the help with TEM measurements. We also thank Millie Gentry for aid with the avidin-CD14 construct and Xavier Michalet for the AFM analyses software. Suggestions and discussions by X.M. and Emmanuel Margeat are greatly appreciated. The fluorescent microscopy was performed at the UCLA/CNSI Advance Light Microscopy Shared Facility. This work has been funded by the National Institute of Health, Grant No. R01 EB000312-04.

\section{References}

1. Alivisatos AP. Science. 1996; 271:933.

2. Nirmal M, Brus L. Acc Chem Res. 1999; 32:407.

3. Efros AL, Efros AL. Sov Phys Semicond. 1982; 16:772.

4. Efros AL, Rosen M. Annu Rev Mater Sci. 2000; 30:475.

5. Qu L, Peng X. J Am Chem Soc. 2002; 124:2049. [PubMed: 11866620]

6. Michalet X, Pinaud F, Lacoste TD, Dahan M, Bruchez MP, Alivisatos AP, Weiss S. Single Mol. $2001 ; 2: 261$.

7. Chan WC, Maxwell D, Gao X, Bailey R, Han M, Nie S. Curr Opin Biotechnol. 2002; 13:40. [PubMed: 11849956]

8. See references in Cumberland S, Hanif K, Javier A, Khitrov G, Strouse GF, Woessner S, Yun S. Chem Mater. 2002; 14:1576.

9. Murray CB, Norris DJ, Bawendi MG. J Am Chem Soc. 1993; 115:8706.

10. Bowen Katari JE, Colvin VL, Alivisatos AP. J Phys Chem. 1994; 98:4109.

11. Peng ZA, Peng X. J Am Chem Soc. 2001; 123:183. [PubMed: 11273619]

12. Hines MA, Guyot-Sionnest P. J Phys Chem. 1996; 100:468.

13. Dabbousi RO, Rodriguez-Viejo J, Mikulec FV, Heine JR, Mattoussi H, Ober R, Jensen KF, Bawendi MG. J Phys Chem B. 1997; 101:9463. 
14. Wang YA, Li JJ, Chen HY, Peng XG. J Am Chem Soc. 2002; 124:2293. [PubMed: 11878983]

15. Wu X, Liu H, Liu J, Haley KN, Treadway JA, Larson JP, Ge N, Peale F, Bruchez MP. Nat Biotechnol. 2003; 21:41. [PubMed: 12459735]

16. Chan WCW, Nie S. Science. 1998; 281:2016. [PubMed: 9748158]

17. Mattoussi H, Mauro JM, Goldman ER, Anderson GP, Sundar VC, Mikulec FV, Bawendi MG. J Am Chem Soc. 2000; 122:12 142.

18. Pathak S, Choi SK, Arnheim N, Thompson ME. J Am Chem Soc. 2001; 123:4103. [PubMed: 11457171]

19. Sun B, Xie W, Yi G, Chen D, Zhou Y, Cheng J. J Immunol Methods. 2001; 249:85. [PubMed: 11226466]

20. Dubertret B, Skourides P, Norris DJ, Noireaux V, Brivanlou AH, Libchaber A. Science. 2002; 298:1759. [PubMed: 12459582]

21. Sukhanova A, Venteo L, Devy J, Artemyev M, Oleinikov V, Pluot M, Nabiev I. Lab Invest. 2002; 82:1259. [PubMed: 12218088]

22. Bruchez M, Moronne M, Gin P, Weiss S, Alivisatos AP. Science. 1998; 281:2013. [PubMed: 9748157]

23. Gerion D, Pinaud F, Williams SC, Parak WJ, Zanchet D, Weiss S, Alivisatos AP. J Phys Chem B. 2001; 105:8861.

24. Goldman ER, Anderson GP, Tran PT, Mattoussi H, Charles PT, Mauro JM. Anal Chem. 2002; 74:841. [PubMed: 11866065]

25. Goldman ER, Balighian ED, Kuno MK, Labrenz S, Tran PT, Anderson GP, Mauro JM, Mattoussi H. Phys Status Solidi B. 2002; 229:407.

26. Parak WJ, Boudreau R, Le Gros M, Gerion D, Zanchet D, Micheel CM, Williams SC, Alivisatos AP, Larabell C. Adv Mater. 2002; 14:882.

27. Dahan M, Laurence T, Pinaud F, Chemla DS, Alivisatos AP, Sauer M, Weiss S. Opt Lett. 2001; 26:825. [PubMed: 18040463]

28. Akerman ME, Chan WC, Laakkonen P, Bhatia SN, Ruoslahti E. Proc Natl Acad Sci USA. 2002; 99:12 617.

29. Jaiswal JK, Mattoussi H, Mauro JM, Simon SM. Nat Biotechnol. 2003; 21:47. [PubMed: 12459736]

30. Kloepfer JA, Mielke RE, Wong MS, Nealson KH, Stucky G, Nadeau JL. Appl Environ Microbiol. 2003; 69:4205. [PubMed: 12839801]

31. Rosenthal SJ, Tomlinson A, Adkins EM, Schroeter S, Adams S, Swafford L, McBride J, Wang YQ, DeFelice LJ, Blakely RD. J Am Chem Soc. 2002; 124:4586. [PubMed: 11971705]

32. Dahan M, Levi S, Luccardini C, Rostaing P, Riveau B, Triller A. Science. 2003; 302:442. [PubMed: 14564008]

33. Larson D, Zipfel W, Williams R, Clark S, Bruchez M, Wise F, Webb WW. Science. 2003; 300:1434. [PubMed: 12775841]

34. Doose, S., Weiss, S. personal communication.

35. Gao X, Chan WC, Nie S. J Biomed Optics. 2002; 7:532.

36. Cobbett CS. IUBMB Life. 2001; 51:183.

37. Dameron CT, Reese RN, Mehra RK, Kortan AR, JCP, Steigerwald ML, Brus LE, Winge DR. Nature. 1989; 338:596.

38. Dameron CT, Winge DR. Trends Biotechnol. 1990; 8:3. [PubMed: 1366570]

39. Dameron CT, Winge DR. Inorg Chem. 1990; 29:1343.

40. Bae W, Abdullah R, Henderson D, Mehra RK. Biochem Biophys Res Commun. 1997; 237:16. [PubMed: 9266821]

41. Whitling JM, Spreitzer G, Wright DW. Adv Mater. 2000; 12:1377.

42. Spreitzer G, Whitling JM, Madura JD, Wright DW. Chem Commun. 2000:209.

43. Whaley SR, English DS, Hu EL, Barbara PF, Belcher AM. Nature. 2000; 405:665. [PubMed: 10864319]

44. Peng XG, Schlamp MC, Kadavanich AV, Alivisatos AP. J Am Chem Soc. 1997; 119:7019. 
45. The size and the concentration of the nanocrystals were evaluated from the first absorption peak position as described in Yu W, Qu L, Guo W, Peng X. Chem Mater. 2003; 15:2854.

46. Laurent T, Killander J. J Chromatogr. 1964; 14:317.

47. Bae W, Mehra RK. J Inorg Biochem. 1998; 70:125.

48. Susi H. Biol Macromol. 1969; 2:5.

49. Ebenstein Y, Nahum E, Banin U. Nano Lett. 2002; 2:945.

50. Manna L, Scher EC, Li L, Alivisatos AP. J Am Chem Soc. 2002; 124:7136. [PubMed: 12059239]

51. Goldman ER, Mattoussi H, Tran PT, Anderson GP, Mauro JM. Mater Res Soc Symp. 2001; 642:J2.8.1.

52. Hiller Y, Gerhsoni JM, Bayer EA, Wilchek M. Biochem J. 1987; 248:167. [PubMed: 3435435]

53. Although the cells were originally derived from a stably transfected clone, some cells in the population have lost expression through continuous passaging. This results in a mixture of av$\mathrm{CD}_{14}{ }^{+}$and av-CD14 ${ }^{-}$cells. For the cell passage used in this set of experiments, the percentage of av-CD14 ${ }^{+}$cells was estimated to be $40 \%$ as judged by biocytin Alexa 594 labeling.

54. Pinaud, F., Weiss, S. personal communication.

55. Lee SW, Mao CB, Flynn CE, Belcher AM. Science. 2002; 296:892. [PubMed: 11988570]

56. Landes C, Burda C, Braun M, El-Sayed MA. J Phys Chem B. 2001; 105:2981.

57. Talapin DV, Rogach AL, Kornowski A, Haase N, Weller H. Nano Lett. 2001; 1:207.

58. Corbett AH, Silver PA. Microbiol Mol Biol Rev. 1997; 61:193. [PubMed: 9184010]

59. Green NM, Konieczny L, Toms EJ, Valentine RC. Biochem J. 1971; 125:781. [PubMed: 5145899]

60. Zhang S, Marini DM, Hwang W, Santoso S. Curr Opin Chem Biol. 2002; 6:865. [PubMed: 12470743]

61. Dawson, RM., Elliott, DC., Elliot, WH., Jones, KM. Data for Biochemical Research. 3. Oxford University Press; New York: 1986. p. 1-31. 


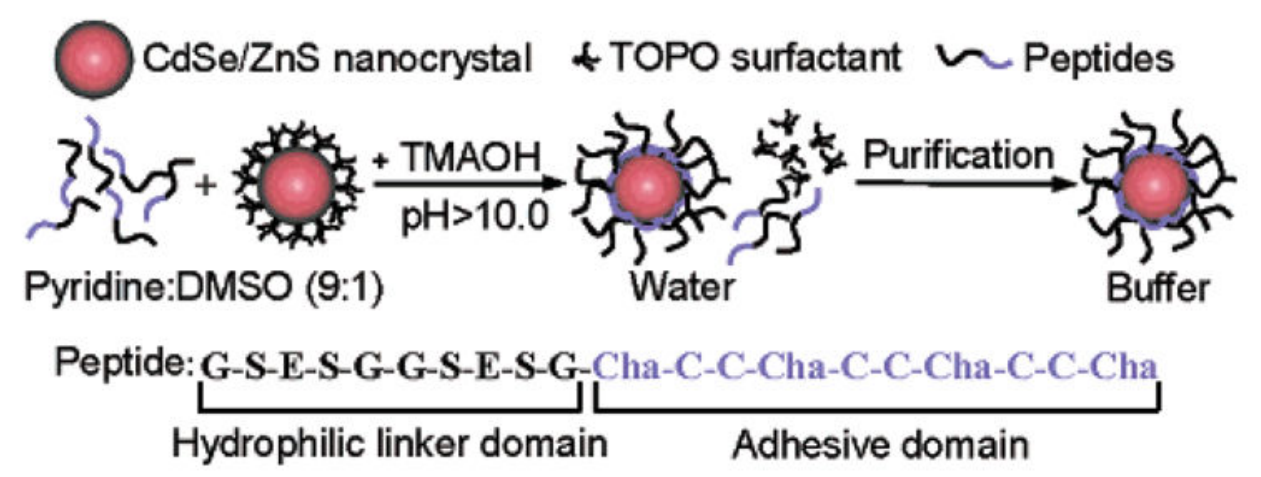

Figure 1.

Schematic representation of the surface coating chemistry of $\mathrm{CdSe} / \mathrm{ZnS}$ nanocrystals with phytochelatin-related a-peptides. The peptide C-terminal adhesive domain binds to the $\mathrm{ZnS}$ shell of CdSe/ZnS nanocrystals after exchange with the TOPO surfactant. A polar and negatively charged hydrophilic linker domain in the peptide sequence provides aqueous buffer solubility to the nanocrystals. TMAOH: Tetramethylammonium hydroxide; Cha: 3cyclohexylalanine. 


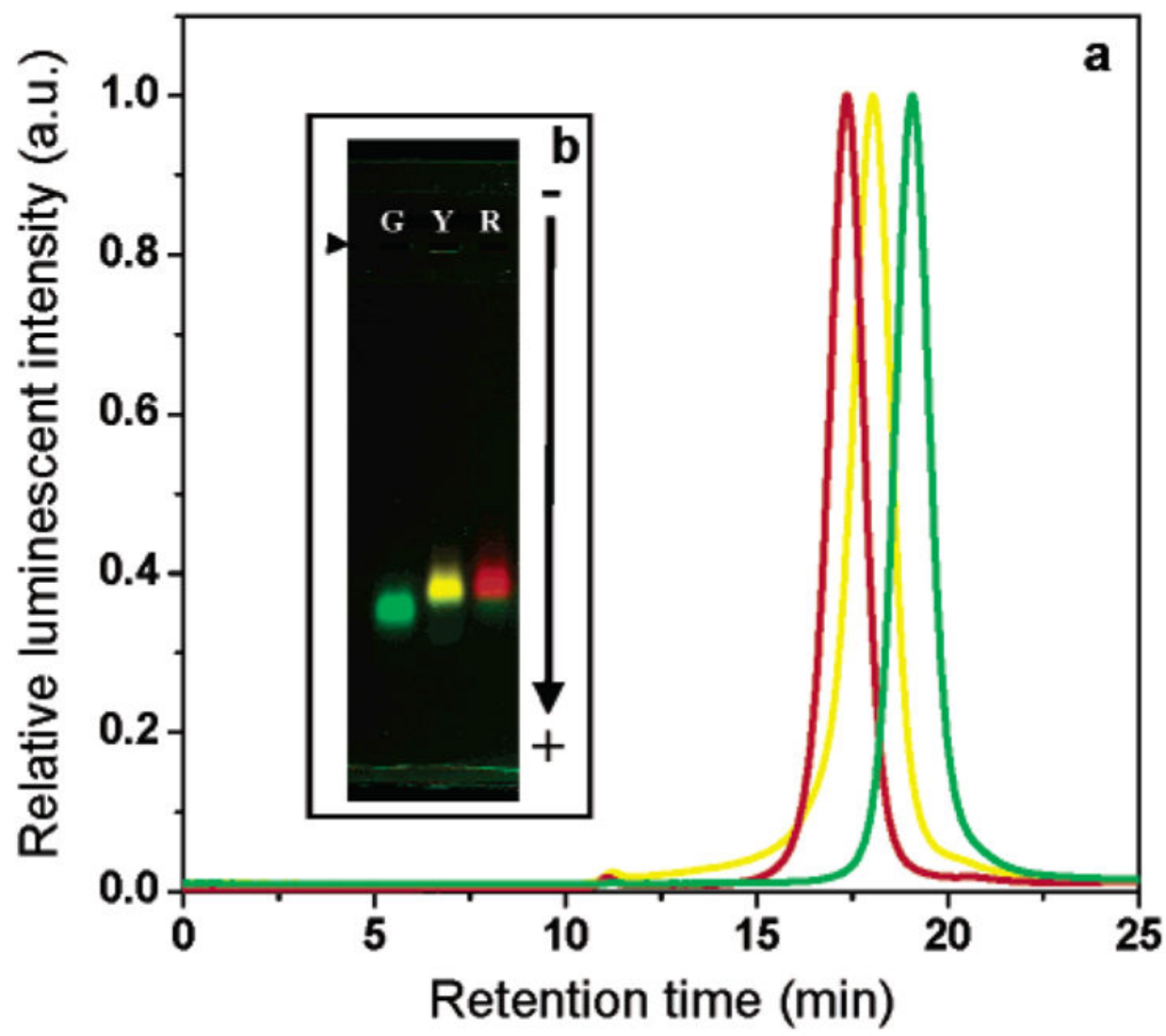

Figure 2.

SE-HPLC and gel electrophoresis of three sizes of peptide-coated CdSe/ZnS nanocrystals. (a) Green $(\mathrm{G})$, yellow $(\mathrm{Y})$, and red $(\mathrm{R}) \mathrm{CdSe} / \mathrm{ZnS}$ nanocrystals emitting at 530, 565 and 617 $\mathrm{nm}$ respectively and coated with peptide $\mathbf{5}$ were separated on a size exclusion column against a $0.1 \mathrm{M}$ PBS mobile phase. The diameter of the peptide-coated nanocrystals was calculated from the elution volumes to be $129.4 \AA( \pm 15 \%), 150.3 \AA( \pm 16 \%)$ and $164.8 \AA$ $( \pm 14 \%)$ for the green, yellow and red samples, respectively. (b) $0.5 \%$ agarose gel electrophoresis of the same three peptide-coated nanocrystal samples in TBE buffer $\mathrm{pH}$ 8.3. (right facing solid triangle): loading wells. -: anode. 

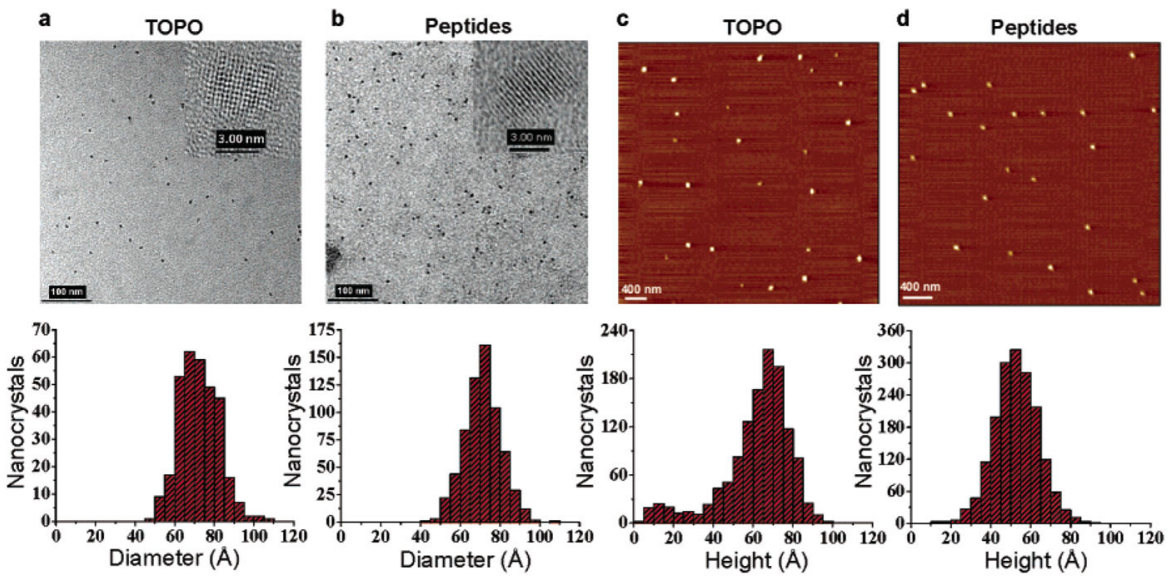

Figure 3.

TEM and AFM size distribution statistics of red emitting TOPO and peptide-coated $\mathrm{CdSe} / \mathrm{ZnS}$ nanocrystals. Size distribution histograms of TOPO-coated nanocrystals (bottom $a$ and c) and the same nanocrystals coated with peptide 4 (bottom b and d) were constructed from low and high resolution (insert) TEM images (top a and b) and AFM images (top c and d). The diameter of the nanocrystals was measured to be $73.8 \AA$ ( $\pm 27 \%$ ) (a), $73.7 \AA( \pm 24 \%)$ (b), $70.7 \AA$ ( $\pm 27 \%$ ) (c), and $55.2 \AA$ ( $\pm 38 \%$ ) (d). 


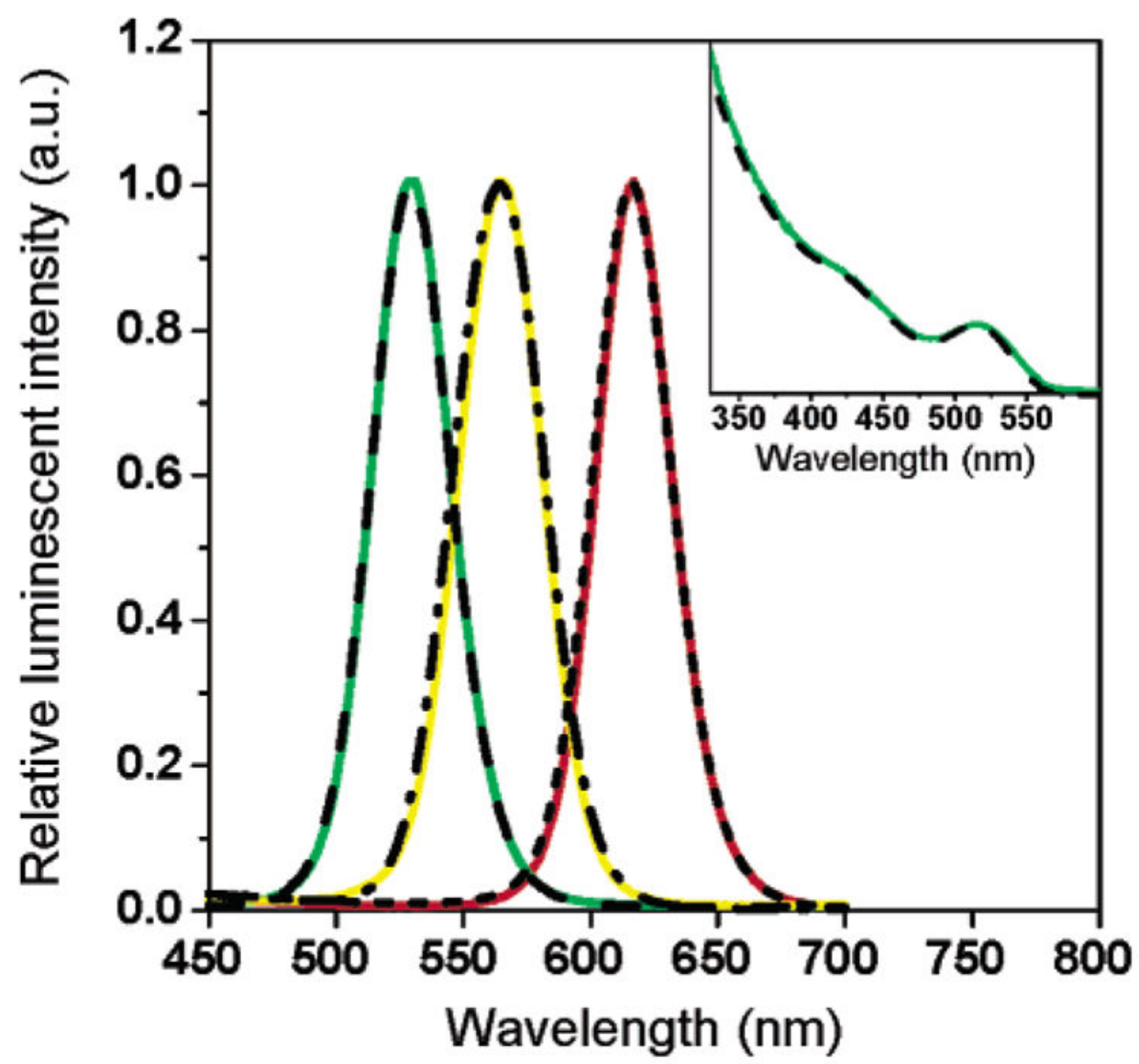

Figure 4.

Comparison of the emission and absorption spectra of TOPO and peptide-coated CdSe/ZnS nanocrystals. Peptide-coated (green, yellow, and red) and TOPO-coated nanocrystals (dash, dash-dot, and short dash) have identical emission spectra after water solubilization with peptide 4. Insert: The absorption of TOPO-coated CdSe/ZnS nanocrystals (dash) is unchanged after peptide coating (green). 
a
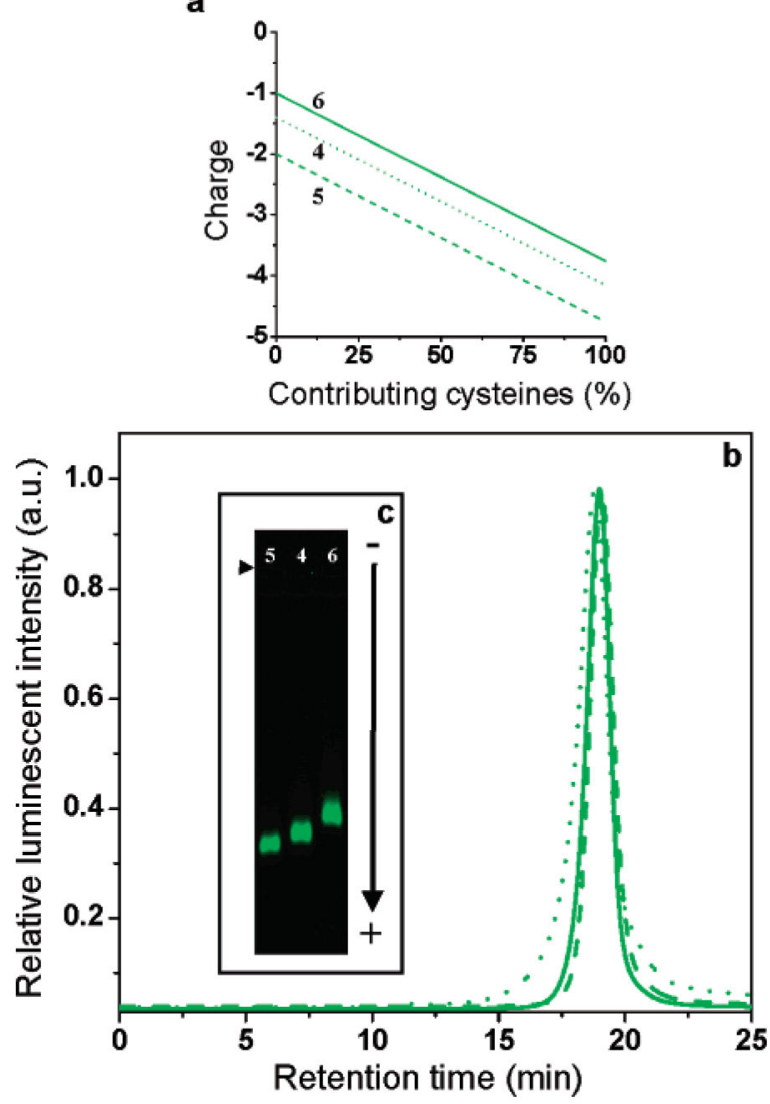

Figure 5.

SE-HPLC and gel electrophoresis of green emitting CdSe/ZnS nanocrystals coated with three peptides of different charge. (a) Theoretical net charge of peptides 5, 4, and $\mathbf{6}$ in TBE buffer $\mathrm{pH}$ 8.3. The charges were calculated from the $\mathrm{pK}$ values of the amino acids' functional groups in each sequence ${ }^{61}$ as a function of cysteine contribution to the charge and assuming a charge of about +0.5 for the non-acetylated $N$-terminal amine of peptide 4 (pK between 8.0 and 9.0) and -1.0 for the succinylation of peptide 6 (pK between 3.0 and 5.0). (b) Nanocrystals coated with peptides 5 (dash), 4 (dot), or $\mathbf{6}$ (solid) have similar retention times on an SE-HPLC column. (c) The same nanocrystals migrate at different positions on a $0.5 \%$ agarose gel, in good agreement with the theoretical charge of each peptide. (right facing solid triangle): loading wells. - : anode. 


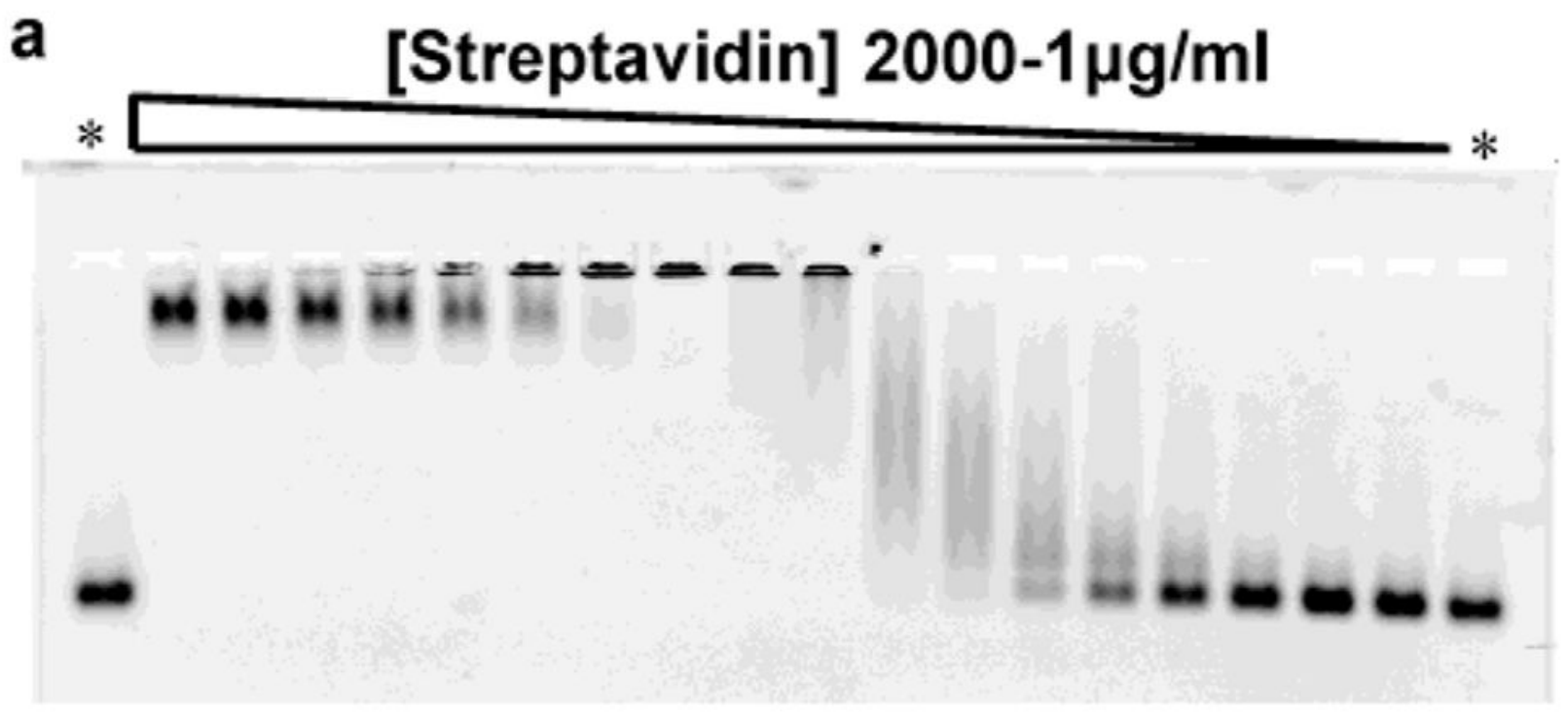

\section{b [Streptavidin] 2000-1 $\mu \mathrm{g} / \mathrm{ml}$}
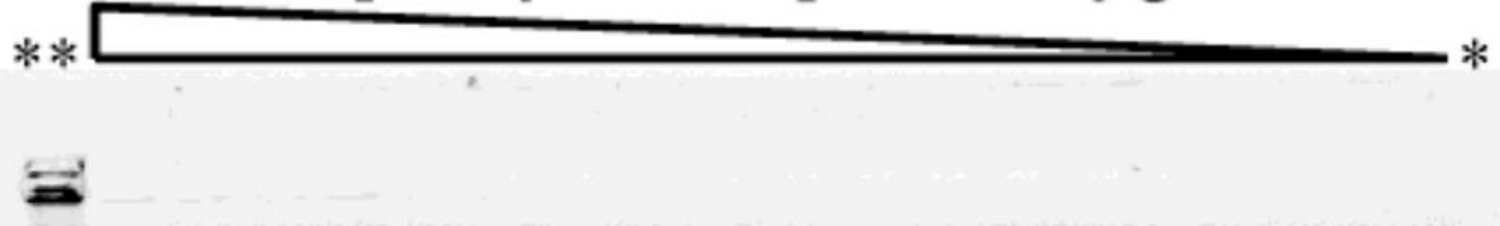

Figure 6.

Streptavidin gel retardation assay with biotinylated peptide-coated nanocrystals. (a) $1 \%$ agarose gel electrophoresis of biotinylated red emitting CdSe/ZnS nanocrystals coated with peptide 8 . The incubation of the nanocrystals with increasing concentration of streptavidin leads to the formation of aggregates and a shift of the nanoparticle band. Large nanocrystal aggregates are unable to enter the gel pores. The gel re-entry at high streptavidin concentration corresponds to the saturation of the nanocrystal surface biotins that prevents aggregation. (b) $1 \%$ agarose electrophoresis of nonbiotinylated $\mathrm{CdSe} / \mathrm{ZnS}$ nanocrystals coated with peptide $\mathbf{6}$ under the same condition as in (a). The concentrations of streptavidin tested were 2000, 1000, 750, 500, 300, 250, 150, 100, 50, 40, 30, 25, 20, 15, 10, 5, 2 and 1 $\mu \mathrm{g} / \mathrm{mL}$. *: no streptavidin; **: biotinylated nanocrystals $+250 \mu \mathrm{g} / \mathrm{mL}$ streptavidin. 


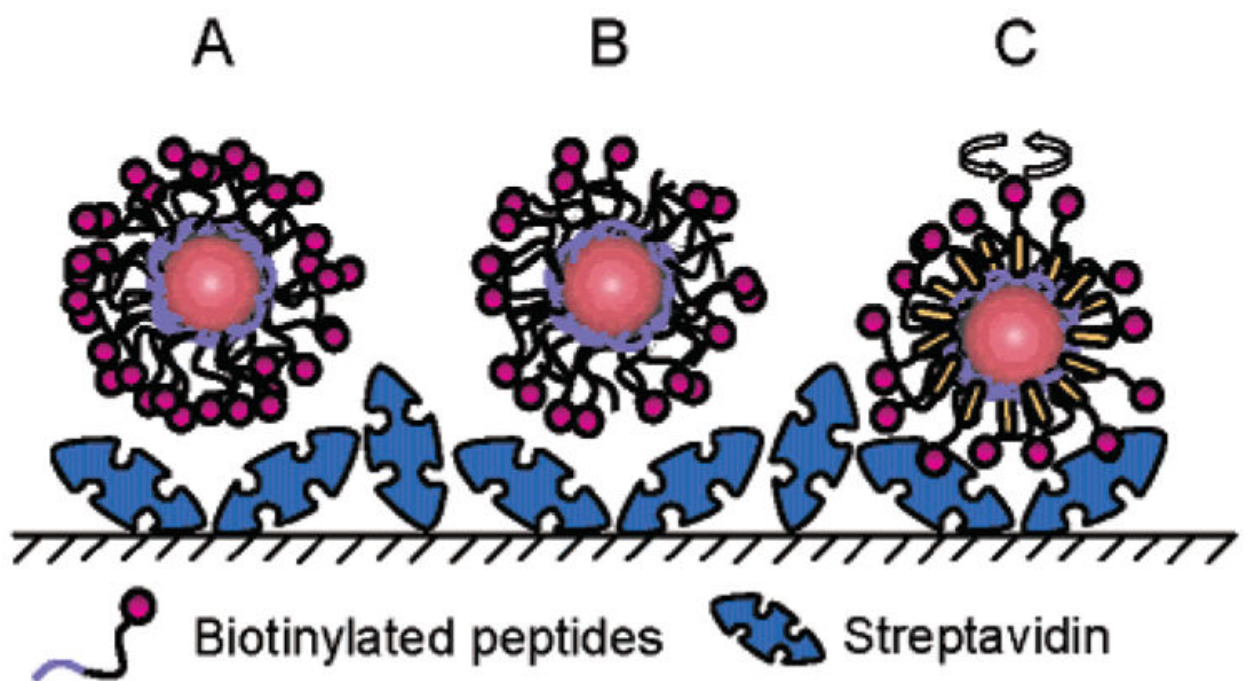

\section{$\Omega$ Non-biotinylated peptides $\sim$ PEG modified peptides}

Figure 7.

Schematic representation of apparent steric hindrance problems associated with ligand density on the nanocrystal surface. Nanocrystals coated only with biotinylated peptides (A) have difficulty binding strepta-vidin bound to a surface probably because of the surface molecular crowding or high density of ligands. Reducing the amount of surface biotin using 1:1 mixtures of biotinylated peptides and nonbiotinylated peptides of similar length (B) does not improve the binding efficiency, the surface being still too crowded. When smaller peptides such as the PEG-modified peptides $\mathbf{9}$ are mixed with the biotinylated peptides (C) the resulting better exposure of biotin enables efficient binding to streptavidin on surface. 


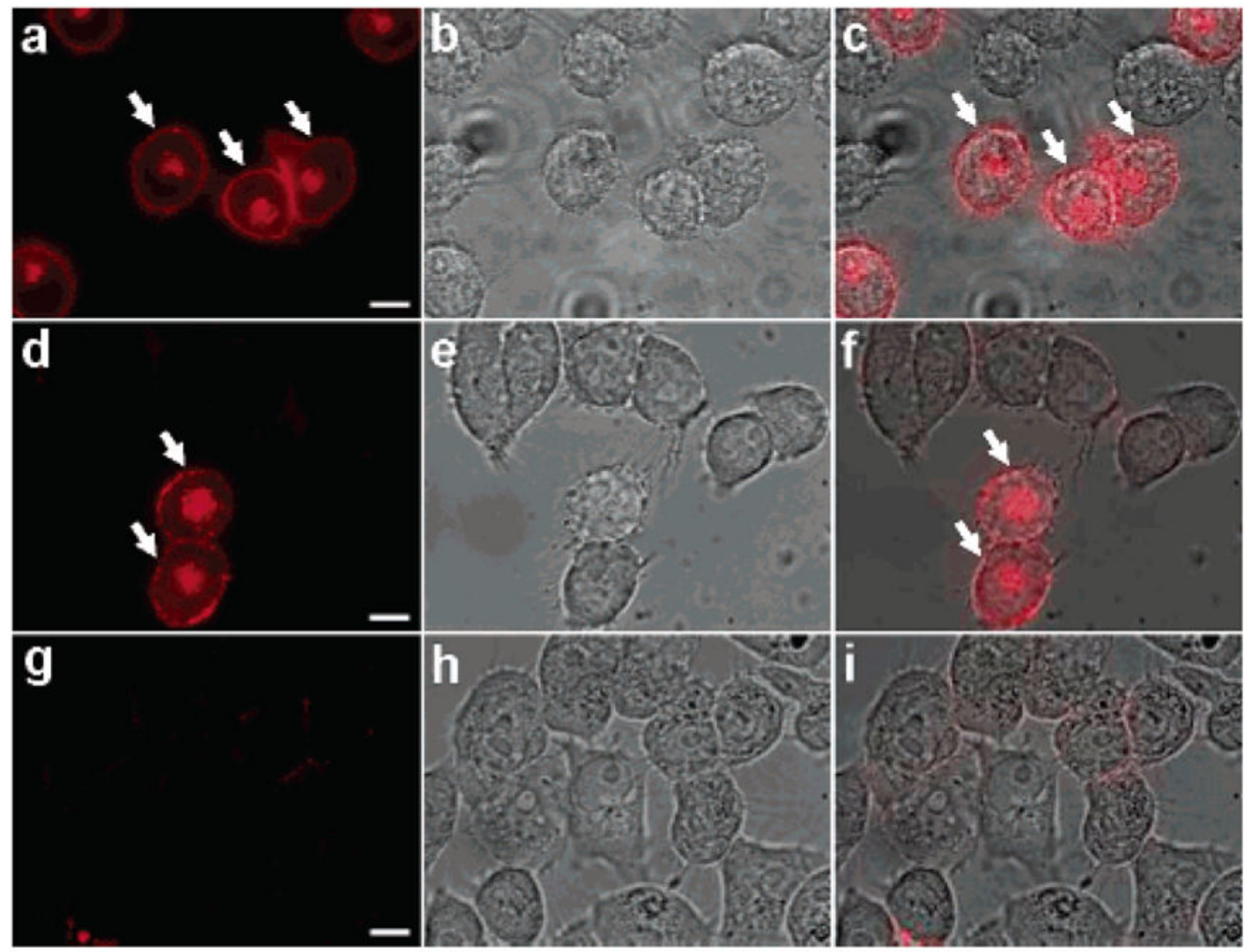

Figure 8.

Targeting of peptide-coated nanocrystals to live HeLa cells. HeLa cells expressing membrane GPI-anchored avidin-CD14 chimeric proteins (av-CD14) were incubated with fluorescent Alexa 594 biocytin $(\mathrm{a}-\mathrm{c})$, red emitting biotinylated $(\mathrm{d}-\mathrm{f})$ or nonbiotinylated nanocrystals ( $\mathrm{g}-\mathrm{i})$. Although many cells are visible in the bright field images (b, e, and h), only the cells expressing the av-CD14 chimeric proteins are labeled with the biotinylated probes and are detected by fluorescence (arrows, a and d). No cell staining over the entire sample could be observed for the nonbiotinylated nanocrystals (g). Overlay of the fluorescence and bright field images (c, f, and i) show the high labeling specificity on avCD14 expressing cells. Scale bar: $10 \mu \mathrm{m}$. 


\section{Table 1}

Sequences of the Phytochelatin-Related a-Peptides Used

\begin{tabular}{|c|c|c|c|}
\hline Designation & NCs solubility Water/Buffer $a$ & $\begin{array}{l}\text { NCs pH } \\
\text { stability } \\
4^{4.0 / 10.0} b\end{array}$ & Sequences $c$ \\
\hline 1 & $+/-$ & ND & Cha-C-C-Cha-C-C-Cha-C-C-Cha-Cmd \\
\hline 2 & $+/-$ & ND & G-G-S-G-G-S-G-G-Cha-C-C-Cha-C-C-Cha-C-C-Cha-Cmd \\
\hline 3 & $-1-$ & $-1-$ & G-R-R-G-E-G-R-R-G-Cha-C-C-Cha-C-C-Cha-C-C-Cha-Cmd \\
\hline 4 & $+/+$ & $+/+$ & G-S-E-S-G-G-S-E-S-G-Cha-C-C-Cha-C-C-Cha-C-C-Cha-Cmd \\
\hline 5 & $+/+$ & $+/+$ & Ac-G-S-E-S-G-G-S-E-S-G-Cha-C-C-Cha-C-C-Cha-C-C-Cha-Cmd \\
\hline 6 & $+/+$ & $+/+$ & Suc-G-S-S-S-G-G-S-S-S-G-Cha-C-C-Cha-C-C-Cha-C-C-Cha-Cmd \\
\hline 7 & $+/+$ & $+/+$ & K-G-S-E-S-G-G-S-E-S-G-Cha-C-C-Cha-C-C-Cha-C-C-Cha-Cmd \\
\hline 8 & $+/+$ & $+/+$ & Biotin-G-S-E-S-G-G-S-E-S-G-Cha-C-C-Cha-C-C-Cha-C-C-Cha-Cmd \\
\hline 9 & $+1-$ & $+/+$ & PEG-Cha-C-C-Cha-C-C-Cha-C-C-Cha-Cmd \\
\hline 10 & $+/+$ & $-/+$ & Ac-G-P-K-K-K-R-K-V-G-G-S-E-S-G-G-S-E-S-G-Cha-C-C-Cha-C-C-Cha-C-C-Cha-Cmd \\
\hline
\end{tabular}

${ }^{a} 100 \mathrm{mM}$ PBS buffer $\mathrm{pH} 7.2$.

$b_{25} \mathrm{mM}$ potassium hydrophthalate buffer $\mathrm{pH} 4.0$ and $25 \mathrm{mM}$ sodium bicarbonate buffer $\mathrm{pH}$ 10.0.

${ }^{c}$ All sequences are written from $\mathrm{N}$ - to $\mathrm{C}$-terminus.

Cmd: carboxamide; Ac: N-terminal acetylation; Suc: N-terminal succinylation; Cha: 3-cyclohexylalanine, PEG: hexaethyleneglycol. ND: not determined. 